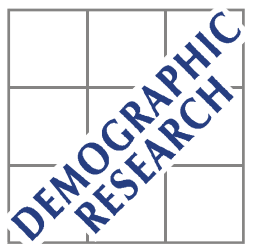

Demographic Research a free, expedited, online journal of peer-reviewed research and commentary in the population sciences published by the Max Planck Institute for Demographic Research Konrad-Zuse Str. 1, D-18057 Rostock · GERMANY www.demographic-research.org

DEMOGRAPHIC RESEARCH

VOLUME 11, ARTICLE 7, PAGES 173-194

PUBLISHED 17 September 2004

www.demographic-research.org/Volumes/Vol11/7/

DOI: 10.4054/DemRes.2004.11.7

Research Article

\title{
Trends in East-West German Migration from 1989 to 2002
}

\section{Frank Heiland}

(C) 2004 Max-Planck-Gesellschaft. 


\section{Table of Contents}

1 Introduction: Data on East-West German Migration since 1989

2 The Two Waves of East-West German Migration 174

3 Distribution Across Origin and Destination Region 178

$4 \quad$ Concluding Remarks 188

$\begin{array}{lll}5 & \text { Acknowledgements } & 189\end{array}$

$\begin{array}{ll}\text { Notes } & 190\end{array}$

$\begin{array}{ll}\text { References } & 192\end{array}$ 
Research Article

\title{
Trends in East-West German Migration From 1989 to 2002
}

\author{
Frank Heiland ${ }^{1}$
}

\begin{abstract}
The purpose of this article is to show recent trends in regional migration from East to West Germany by combining data from the Statistisches Bundesamt from 1991 to 2002 with data from the Zentrales Einwohnerregister der DDR from 1989 to 1990. We document that annual gross outmigration rates peaked at the time of the Reunification, fell sharply thereafter, but rose steadily from the 1997 until 2001 to reach levels obtained prior to the Reunification. While Mecklenburg-Vorpommern and Brandenburg experienced less outmigration before the Reunification compared to Thüringen, Sachsen, and Sachsen-Anhalt, they are the regions that have experienced the highest pace of outmigration since then. With the exception of the increasing popularity of the Berlin region, the distribution of East to West migrants across West Germany is fairly stable over time: migrants continue to favor the large industrial provinces of Baden-Württemberg, Bayern, Nordrhein-Westfalen, and Niedersachsen.
\end{abstract}

\footnotetext{
${ }^{1}$ Department of Economics and Center of Demography and Population Health, The Florida State University, Tallahassee, FL 32306-2180, USA. Phone: (1)-(850)-644-7083. Email: fheiland@ @su.edu.
} 


\section{Introduction: Data on East-West German Migration since 1989}

Since Germany unified on 1 October 1990, total migration flows between the German Bundesländer (the fifteen administrative provinces or 'Länder') are available for all eleven Länder in the West (including Berlin) and the five Länder in the East (cf. Map in Figure 1). The data are obtained from aggregating residential registration records (a person who moves to another Land within Germany must register in her new community, which leads to deregistration at the location of origin). The Statistisches Bundesamt (SB) makes these data available in its annual Statistisches Jahrbuch der Bundesrepublik Deutschland (1993-2003) and through its web-based data service (cf. www.destatis.de). The SB data have been investigated by several authors, most recently Wendt (1993/94), Burda (2000), Hunt (2000), Parikh and van Leuvensteijn (2002), and Heiland (2003). [Note 1] The only existing population-level data set that covers the important period before the Reunification is from the Residence Department of the German Democratic Republic (GDR), Zentrales Einwohnerregister Berlin-Biesdorf (ZER). [Note 2] The ZER ceased collecting data in the summer of 1992.

The ZER data have first been discussed in Grundmann (1998). He analyzes various aspects of the distributions of East-West migrants between 1989 and 1992. He presents the distributions for Mecklenburg-Vorpommern and Thüringen (Grundmann 1998, pp. 183-184) but does not discuss the development since 1992. In this note we present the complete history of annual migration from the five regions in the East to the eleven regions in the West since 1989, using the outmigration distributions and migration flows in the ZER data for the years 1989 and 1990 and the SB data thereafter. [Note 3] From the distributions and the aggregate migration flows, we also calculate the total number of migrants from a region in the East to a region in the West for these years. For the years between 1991 and 2002, we use the annual East-West migration data from the SB. [Note 4] We note that the data for the region of the city of Berlin are incomplete. Data on migration into East Berlin before 1991 from East Germany are unavailable and a distinction between West and East Berlin after 1992 is not possible. Hence, in the tables and charts

presented in this note, Berlin before 1991 represents (former) West Berlin and West and East Berlin combined thereafter.

\section{The Two Waves of East-West German Migration}

The dramatic political events in the GDR that led to the Reunification of the two Germanys in October 1990 provide the background to the initial wave of East to West migration. Before the summer of 1989, emigration from the GDR was severely restricted. 


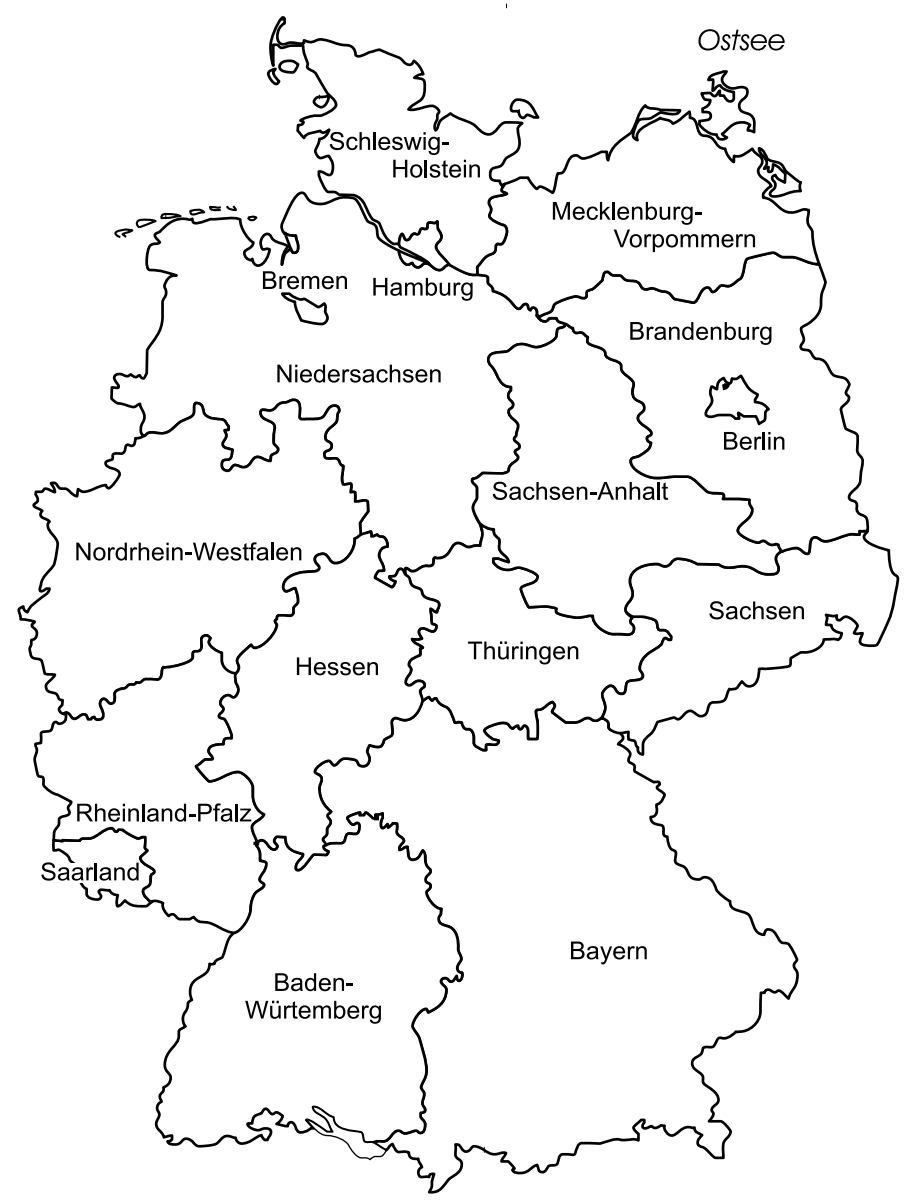

Figure 1: Map of German Bundesländer (Definition of October 1990) 
During the summer of 1989, a reduction in patrol at the Hungarian border enabled East German tourists enter West Germany via Austria. Mounting pressures from the East German public for political and economic reform led to the fall of the Berlin Wall in November, which made migration from East to West Germany (and beyond) possible. Table 1 displays the distribution of migrants from East Germany (excluding East Berlin) across the West German Länder and the total number of East-West migrants between 1989 and 2002. To account for the differences in population size, [Note 5] Figure 2 shows the corresponding outmigration rates. [Note 6] Between 1989 and 1990, almost 600,000 East Germans, roughly $3.7 \%$ of the population in the region of the former GDR (excl. East Berlin), emigrated to West Germany (incl. West Berlin). [Note 7]

The fear of missing this unexpected window of opportunity to leave the GDR likely the dominant motive of East-West migration in 1989 - faded in March 1990 by the outcome of the first free national election held in the GDR. The election strengthened the influence of the reformist parties and negotiations towards closer cooperations with West German officials began. This outcome coincided with a decline in the outmigration rate (cf. Wendt 1993/94, p. 526; Grundmann 1998, p. 176). Soon afterwards, on 1 July 1990, East and West Germany entered a comprehensive monetary, economic, and social union that marked an important step towards unification, thereby further reducing the uncertainty about the possibility of future travel and relocation.

From 1991 until the mid-1990s, the pace of East to West migration cooled off substantially — the annual outmigration rate in 1994 was $1.04 \%$, which is about half its 1990 level. The initial optimism, the speedy wage convergence in the early 1990s that translated into rising living standards for many in the East and fewer job opportunities in the West after 1992, may explain the relatively low outmigration rates during the early to mid-1990s. The average real wage gap between East and West Germany narrowed quickly to about $28 \%$ by 1994 (cf. Sinn 2000, Fig. 9), potentially giving East Germans less incentive to leave. Data on wages of manufacturing workers by region presented in Figure 10 illustrate the considerable pace of the wage increases in the East during the early 1990s. [Note 8] In addition, after the reunification-induced boom, the West German economy followed western Europe into a recession that lasted from late 1992 to 1994. As shown in Figure 9, the unemployment rate in the West German provinces dropped in the early 1990s but started to rise at the onset of the recession, which in turn reduced the opportunities for East Germans to move for a job in the West. It appears that these incentives outweighed the reasons to migrate to the West, such as rising unemployment in the East, soon after monetary unification (cf. Akerlof et al. 1991 and Figure 9).

The outmigration trend data show that East to West migration rose strongly since 1997 and peaked in 2001 at $1.64 \%$. In 2002 - the most recent year available - the outmigration rate is $1.55 \%$, which is $50 \%$ higher than in 1994 . The second wave of outmigration coincided with several important economic developments that may have triggered this 


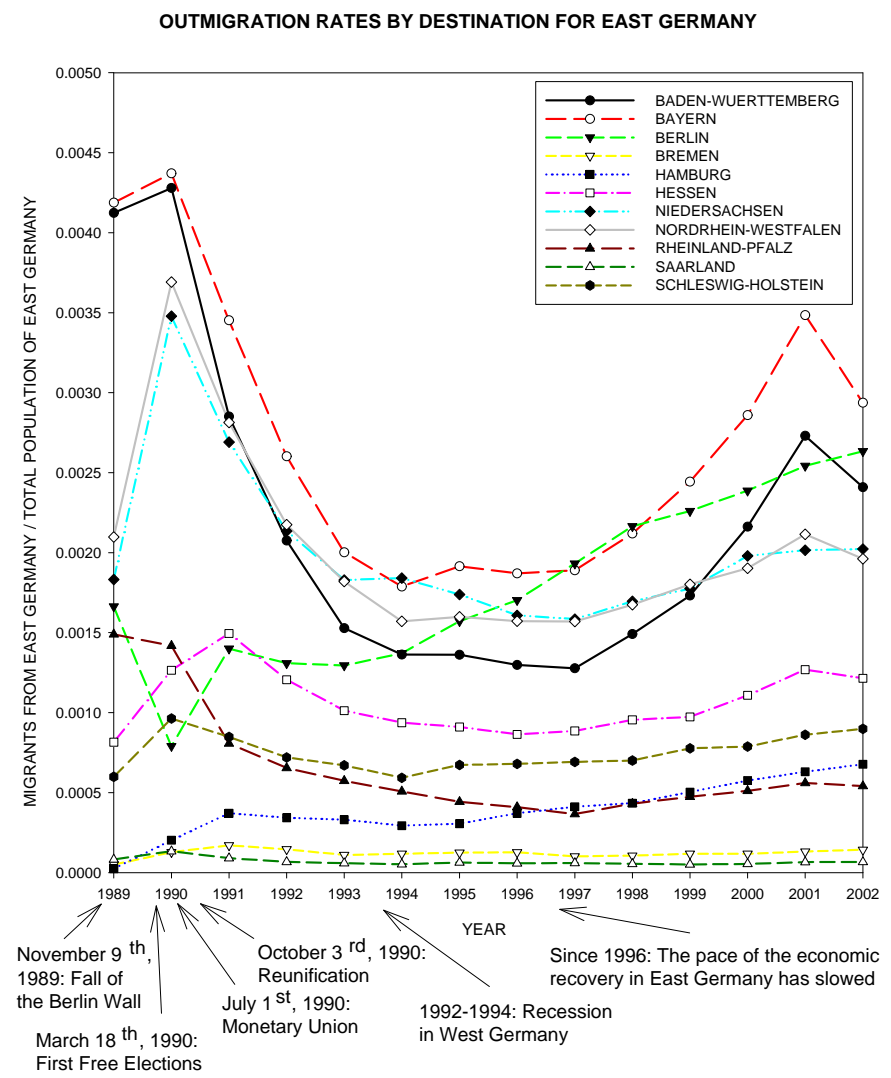

Figure 2: Aggregated Outmigration Rates (Destination Region) 
rise. First, wage convergence between East and West Germany has essentially halted since 1995 (cf. Sinn 2000, Fig. 9 and Figure 10). Second, the employment situation in the East stabilized only temporarily during 1994-1995 as shown in Figure 9. Between 1995 and 2002, the average unemployment rate in the East (incl. East Berlin) increased from $14.9 \%$ to $18.0 \%$ - a level more than twice as high as in the West. [Note 9] Figure 9 shows that 1997 and 1998 were the worst years for labor markets in the East German Länder, and since then unemployment has remained above the highest levels reached in the 1992-1994 period. Third, and perhaps most importantly, the West German labor markets improved substantially after 1997 (cf. Figure 9).

The deteriorating economic conditions in the East have been attributed to challenges commonly encountered by regions in transition from centralized to market economies (e.g., the initial lack of competitive products) as well as the rapid wage increases in the East that were not justified by rising labor productivity. The East German firms that existed before unification experienced a dramatic labor cost squeeze after the monetary unification of the two Germanys in July 1990 when wages and salaries had to be paid in Deutschmarks (West German currency). [Note 10] In addition, powerful West German unions helped to 'bargain' for new labor contracts in the East that mandated further large raises. [Note 11] In sum, the second outmigration wave probably resulted from disincentives to stay in the East, primarily the worsening job prospects there after 1995 and improving employment conditions in the West after 1997.

\section{Distribution Across Origin and Destination Region}

The first observation is that the u-shaped ('two waves') relationship of outmigration over time that we found at the aggregate level (Table 1) also holds for most of the sourcedestination pairs as shown in Figure 2. The exception is the region of the city of Berlin, which has become increasingly important thanks to its expanding role as the political and administrative center of unified Germany. Accordingly, migration into Berlin has steadily increased. [Note 12]

Tables 2-6 and the corresponding Figures 3-8 depict the distribution of migrants over time and across the West German Länder for the five East German regions (see Map in Figure 1). We note that the migration distributions of the East German Länder, Mecklenburg-Vorpommern, Sachsen, Sachsen-Anhalt, Thüringen, and Brandenburg display a dynamics similar to that at the aggregate level: outmigration was highest in 1989-1991, bottomed in 1996-1997, and increased until 2001 (see Figure 3). Brandenburg deviates from the pattern somewhat as outmigration from that region already began to rise in 1995 . The increase is due to the substantial flow of migrants from Brandenburg to Berlin as shown in Figure 8 and Table 6. Berlin received a popularity boost after 1991 when the 


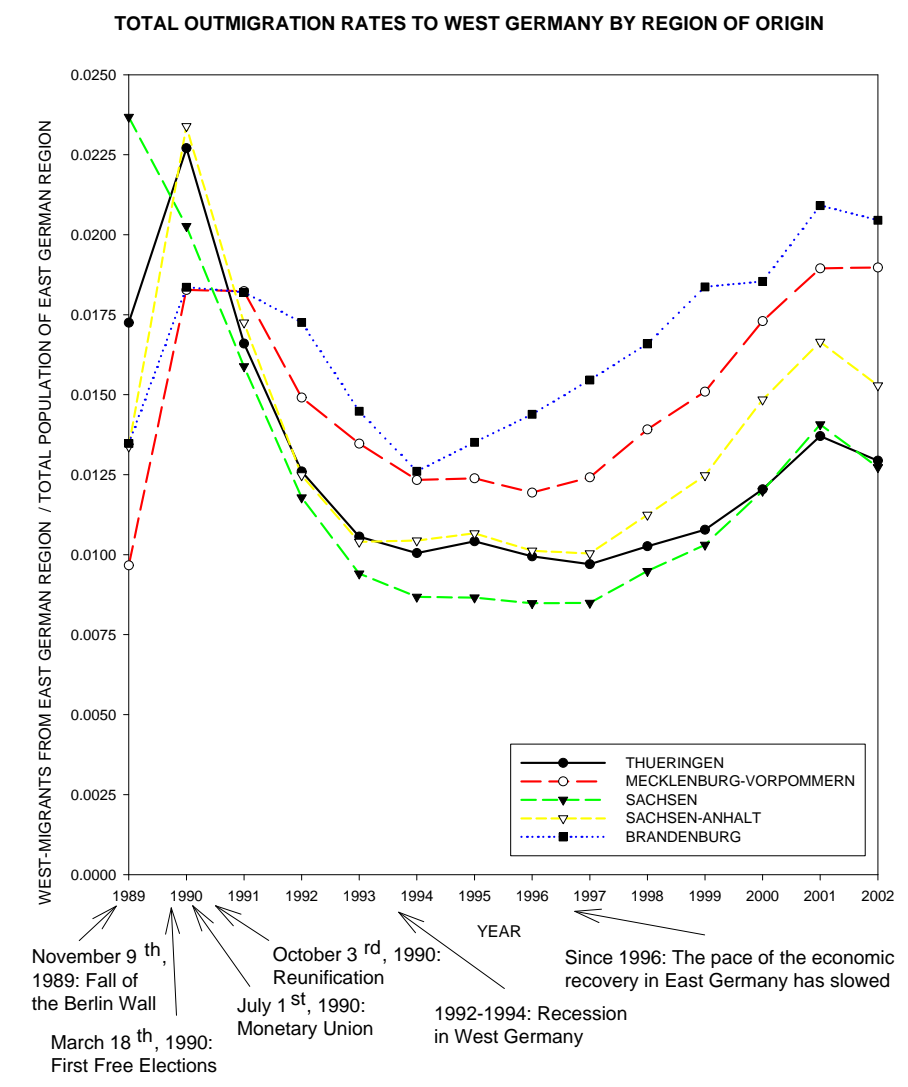

Figure 3: Aggregated Outmigration Rates (Origin Region) 


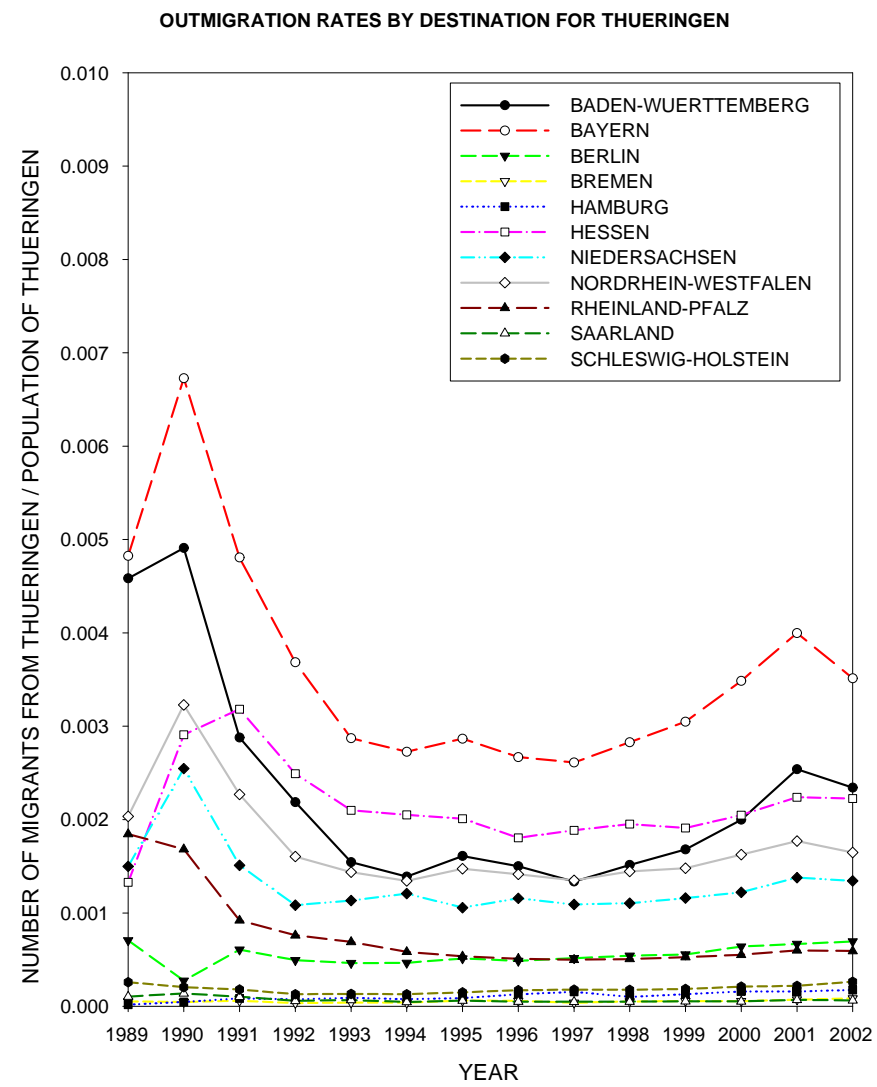

Figure 4: Migration from Thüringen to Western Regions 
OUTMIGRATION RATES BY DESTINATION FOR MECKLENBURG-VORPOMMERN

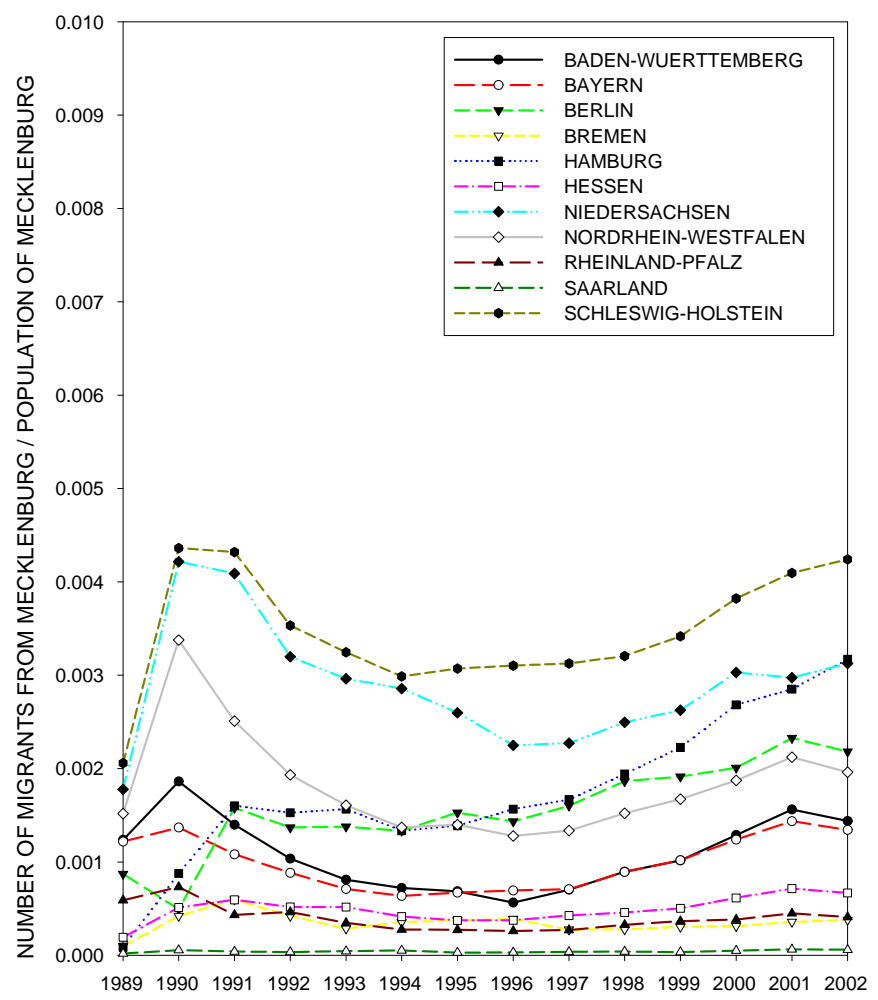

YEAR

Figure 5: Migration from Mecklenburg-Vorpommern to Western Regions 


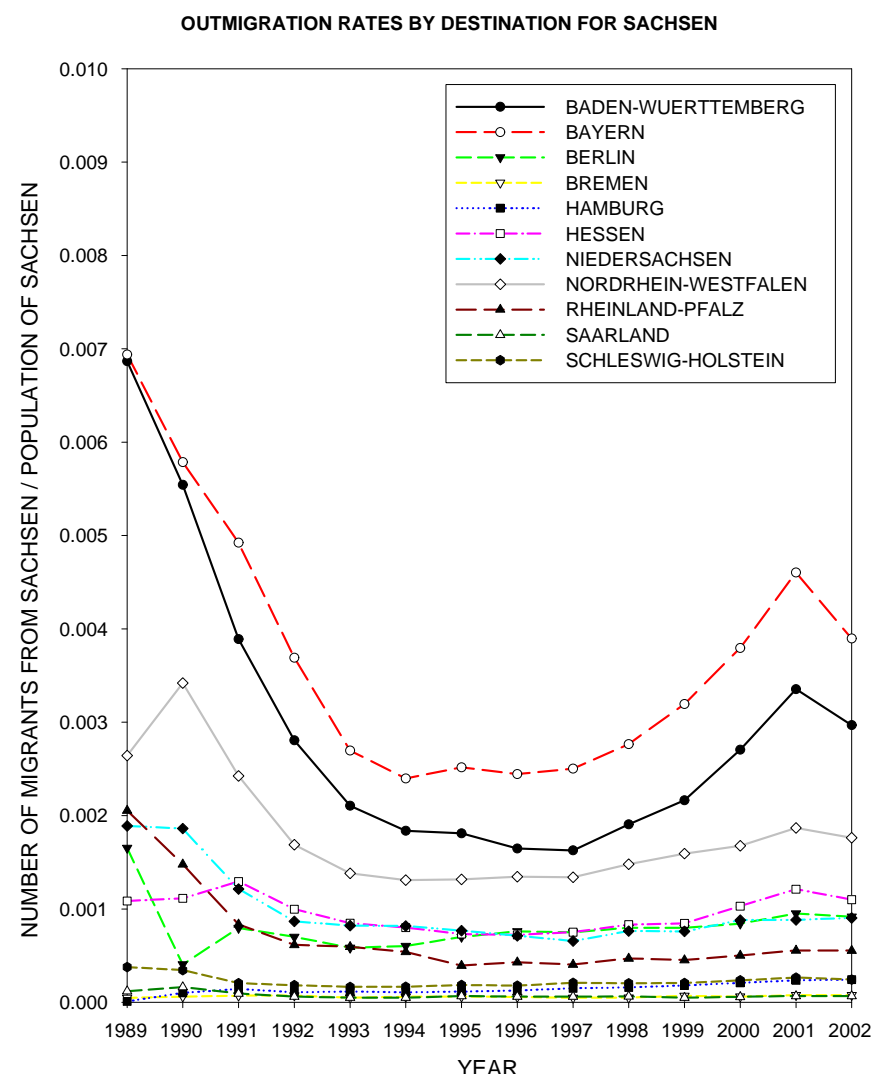

Figure 6: Migration from Sachsen to Western Regions 


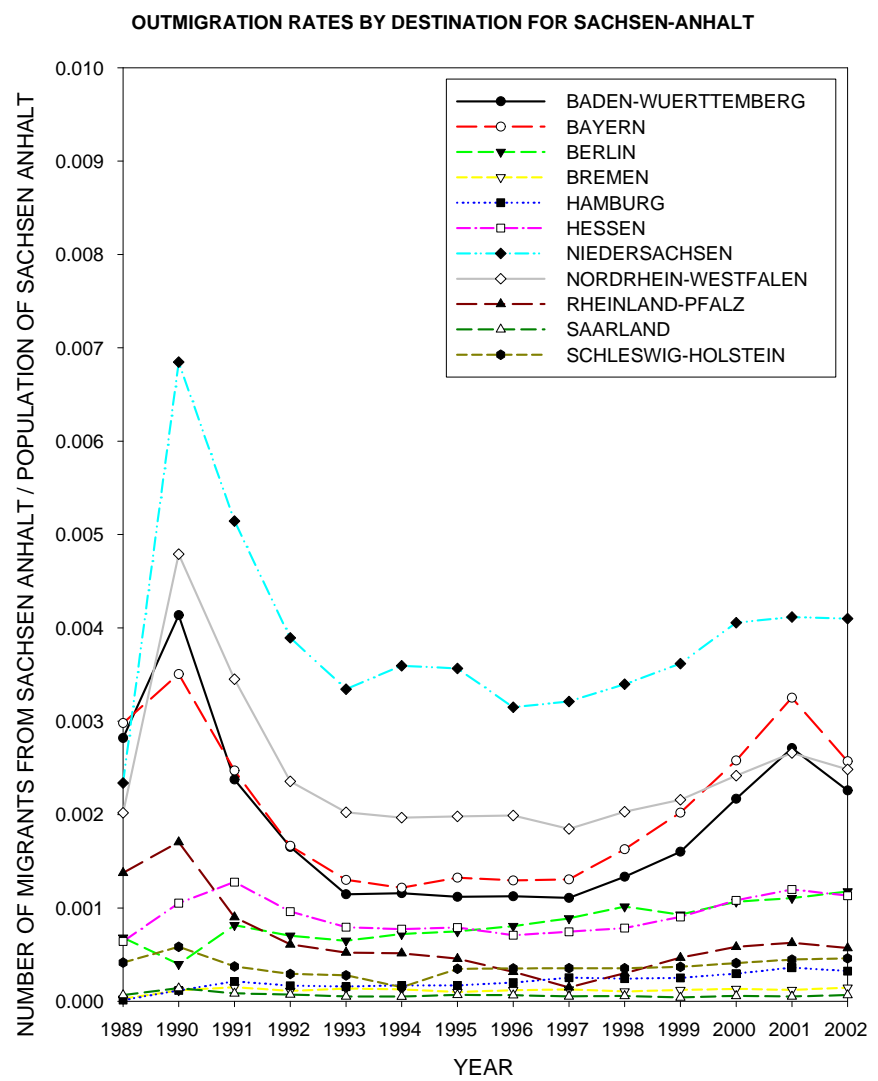

Figure 7: Migration from Sachsen-Anhalt to Western Regions 
OUTMIGRATION RATES BY DESTINATION FOR BRANDENBURG

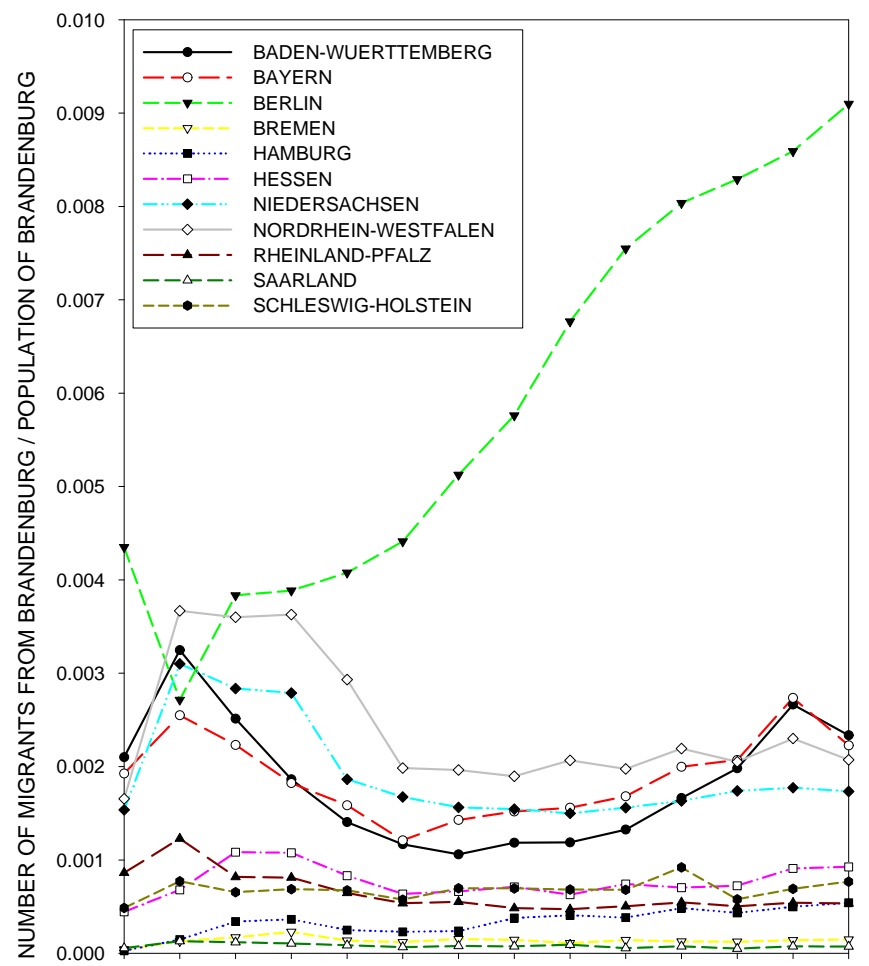

19891990199119921993199419951996199719981999200020012002

YEAR

Figure 8: Migration from Brandenburg to Western Regions 
German parliament in the former capital of Bonn decided to make Berlin the capital of Germany again. The proximity of Brandenburg to the increasingly attractive region of Berlin, in turn, explains the rise of Brandenburg from a region with lower outmigration than most East German provinces in the early 1990s to the region with the fastest pace of outmigration (cf. map of German Länder in Figure 1).

Other interesting differences between the regions in the East with regard to the overall likelihood of departing to the West exist. Like Brandenburg, Mecklenburg-Vorpommern also initially displayed a lower outmigration rate than the other three regions in the East, but outmigration has been higher there than in those regions since 1991. The slow start of Mecklenburg-Vorpommern may have resulted from its remote location (cf. Figure 1; Grundmann 1998). The strong outmigration in recent years may be caused by a persistently weak job market. As Figure 9 shows, Mecklenburg-Vorpommern is the region with the second highest unemployment rate (after Sachsen-Anhalt). We also note that Thüringen experiences a relatively slow pace of outmigration - especially given its proximity to the West - while it also enjoys the lowest unemployment rates of all regions in the East (cf. Figure 9).

The level of the outmigration rates experienced by the western regions remains fairly stable over time for all departure regions (cf. Figures 2,4-8). This suggests that the relative attractiveness of the West German Länder is changing little over the period under study. The only strong 'outliers' in addition to Berlin (most visible for Brandenburg as shown in Figure 8) are the outmigration rates from Thüringen to Hessen during 1989 and 1990 where the rates are below those of Baden-Württemberg and Nordrhein-Westfalen (cf. Figure 4), and from Mecklenburg-Vorpommern to Hamburg which receives more migrants over time (cf. Figure 5). Looking at potential determinants of the migration distribution by region, we note that unemployment rates and wages by region - as shown in Figures 9 and Figure 10 - display a similarly stable ordering over time that is consistent with the outmigration distribution pattern.

The outmigration distributions suggest that proximity to the destination region is positively associated with migration to that destination. For example, Bayern and BadenWürttemberg are similar in terms of their respective population sizes and economic conditions. However, Bayern is further east than Baden-Württemberg and hence lies somewhat closer to Thüringen. Indeed, the outmigration rates from Thüringen to Bayern are greater than to Baden-Württemberg (on average at least $0.1 \%$ as shown in Figure 3).

The outmigration rates may also be positively associated with population size in the source region. For example, Nordrhein-Westfalen, the Bundesland with the largest population, is more frequently chosen by East-West migrants from Thüringen than Niedersachsen - the fourth largest province - despite the fact that the latter is a neighbor of Thüringen. Furthermore, in comparing the area-rich regions to the small but densely populated city-regions of Berlin, Bremen, and Hamburg, we find that the latter attract a 
UNEMPLOYMENT RATE IN GERMANY BY REGION

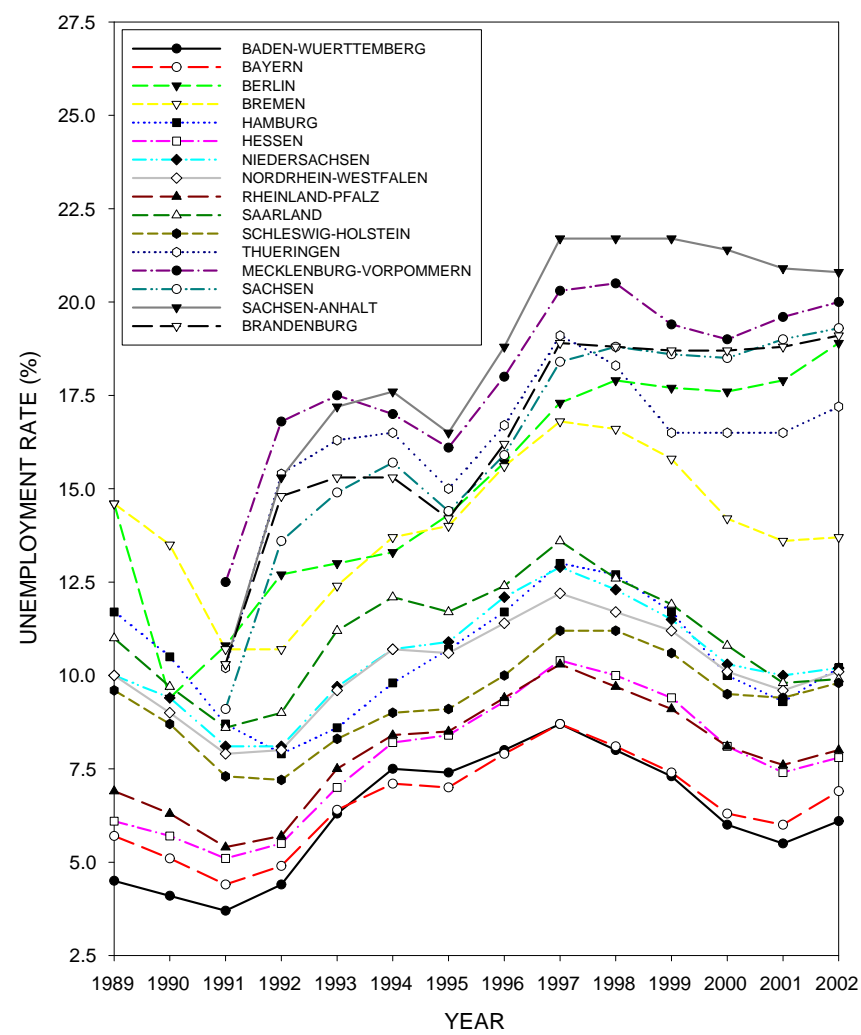

Figure 9: Trends in Unemployment Rates by Region (Source: Statistisches Bundesamt, Statistisches Jahrbuch various years) 


\section{WEEKLY GROSS NOMINAL MANUFACTURING WAGES IN GERMANY BY REGION}

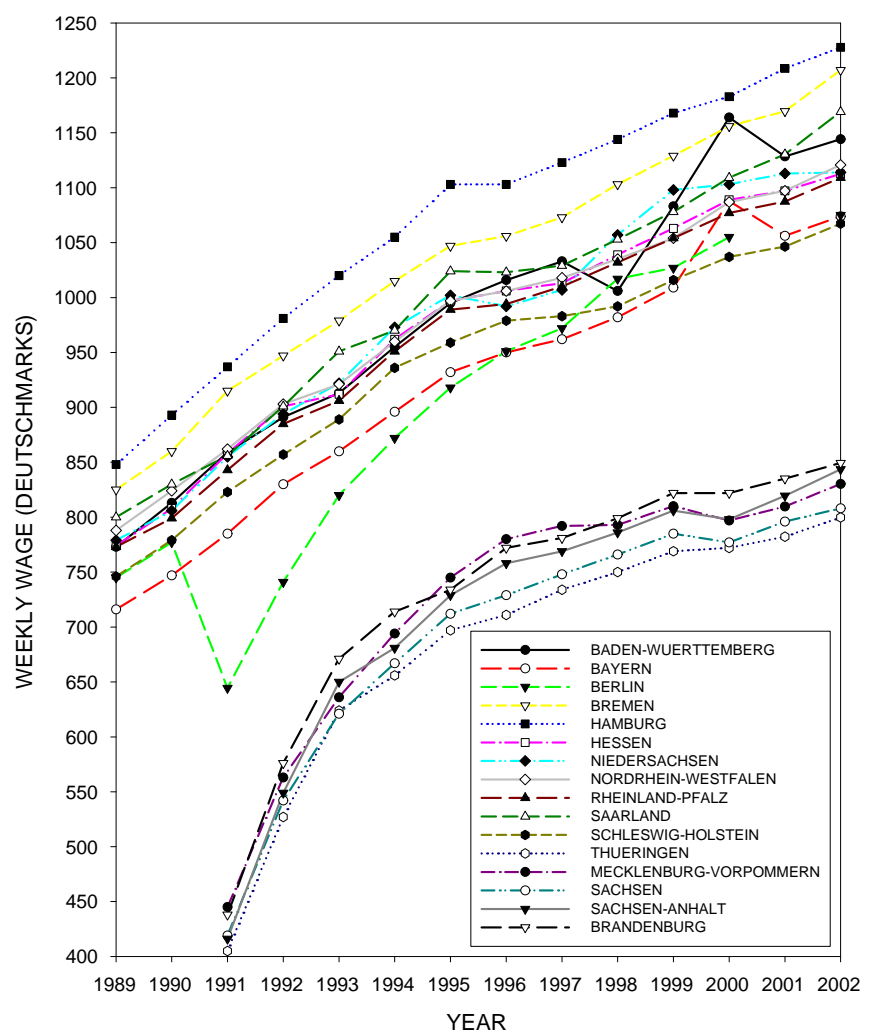

Figure 10: Trends in Wages by Region (Source: Statistisches Bundesamt, Statistisches Jahrbuch various years; the value for Berlin in 2001 is not available) 
significant share of the migrants. A larger population size will typically be associated with a larger labor force and hence more job opportunities. In the case of the city regions, other factors such as location, the amenities of urban living, and high pay (cf. Figure 10) likely play an important role as well.

Finally, the relative employment conditions may also explain how migrants are distributed across regions. The Bundesländer with the lowest unemployment rates, Bayern and Baden-Württemberg (cf. Figure 9), receive considerable flows of migrants even from more distant regions. For example, the outmigration rate from Mecklenburg-Vorpommern to those regions is greater than to Hessen which lies somewhat closer but has experienced higher unemployment. Also, Baden-Württemberg and Bayern were initially much more attractive destinations to potential migrants from Thüringen and Sachsen than, for example, Nordrhein-Westfalen, even though the latter has a much larger population and is only slightly further from these regions. However, the relatively large manufacturing sector in Bayern and in particular in Baden-Württemberg also leads to more dramatic changes in employment opportunity over the business cycle. This may explain that migration into these regions exhibits the largest swings. When the Reunification-induced boom for the Western manufacturing industry ended in late 1992, job prospects in the two southern provinces quickly worsened and Nordrhein-Westfalen became a more popular destination than Baden-Württemberg. However, migration into the latter took off much faster as soon as labor market conditions improved (cf. Figure 9).

\section{Concluding Remarks}

The primary focus of this article was to assemble a data set that provides researchers and policy makers with a more complete picture of the development of East to West migration by region before and after German unification.

We documented two waves of East-West migration. The first one, 1989-1990, was triggered by the opportunities and uncertainties before the Reunification; the second one, since 1997, coincides with economic stagnation in the East and improving job prospects in the West. During the second wave, outmigration rates to the West increased across all East German Länder and reached levels close to those observed prior to the Reunification. In fact, the annual gross outmigration probability in Mecklenburg-Vorpommern and Brandenburg has been greater in recent years than in 1989-1990. The trends by destination region indicate that during the second wave of East-West migration, the economically strongest regions in West Germany, Baden-Württemberg and Bayern, are again the most favorite destinations of East-West migrants. On the other hand, Berlin (incl. East Berlin) is the only destination that has consistently attracted more East-West migrants since 1993 - many from nearby Brandenburg. 
We provided some discussion of the political and socioeconomic background that has shaped East to West migration in Germany over time and across regions. Further study of the determinants of the dynamic and distributional aspects of migration during this important transition period is needed. The data presented here should be useful to conduct such analysis.

\section{Acknowledgements}

I am indebted to Siegfried Grundmann for providing the outmigration distributions and the aggregated East-West migration flows based on his calculation from the ZER data. I thank Alexia Fürnkranz-Prskawetz, Warren C. Sanderson, and Jochen Fleischhacker for valuable support at an early stage of this project. I am also indebted to two anonymous referees for their helpful comments. Assistance in preparing this article was provided by Michael Creswell. This research was funded, in part, by a First Year Assistant Professor Award from The Florida State University. 


\section{Notes}

1. Regional data on mobility in Germany is also provided by the the Federal Office for Building and Regional Planning as used in Maretzke and Möller 1993 and Maretzke 1998.

2. A related literature exists that relies on survey data (Hunt 2000; Alecke and Untiedt 1999; Burda 1993; Burda et al. 1998; Pischke et al. 1994; Schwarze 1996; Wagner 1998; Brückner and Trübswetter 2004).

3. See Dorbritz and Speigner 1991, Wendt 1993/94, and Grundmann 1998 for helpful discussions of immigration and emigration in East Germany before 1989.

4. Comparing the outmigration distributions found in the ZER data to those from the SB data for 1991 - the period that is available in both data sets — we found that the distributions across the west German Länder are broadly consistent. The ZER data report somewhat lower levels of total East-West migration than the SB as noted previously by Grundmann 1998, p. 170 (footnote 32).

5. Mecklenburg-Vorpommern has the smallest population with 1.8 Million whereas Sachsen is the largest province with a population of 4.4 Million in 2002 (cf. Statistisches Bundesamt: Statistisches Jahrbuch 2003, p. 59).

6. The (gross) outmigration rate is defined for some source region $s$ and some destination region $d$ as the ratio of the total number of migrants from $s$ who enter $d$ during that period over the population size of $s$. In our computation of the outmigration rate we use the size of the residence population at the beginning of the calender year in the region of interest based on ZER and SB data. The outmigration rate can be interpreted as the probability that a person migrates from $s$ to $d$ within a given period.

7. East-West migration affected Germany and other Western European countries more broadly after the dissolution of socialism in Eastern Europe. For example, in 1992 Germany received 1.5 million new immigrants (a net inflow of 800,000) including more than 400,000 new asylum seekers and ethnic German refugees (cf. Zimmermann 1995, p. 47).

8. We note that the initially rapid gains in living standards of (employed) East Germans suggested in the graph holds also after taking into account that consumer prices grew faster in the East than in the West during that time as shown, for example, in Heiland (2003). 
9. The unemployment rates are taken from the Statistisches Jahrbuch 1997, p. 124 a publication by the Statistisches Bundesamt and Arbeitsmarkt 2002, p. 17 a publication by the Bundesanstalt für Arbeit, respectively.

10. For political reasons the monetary union specified a 1:1 adjustment rate of East and West German currency for wages and prices which implied an estimated 350\% appreciation of the East Mark (see e.g., Akerlof et al. 1991 and Franz and Steiner 1999).

11. In Germany wages are set periodically in a bargaining procedure that takes place on a regional level. The resulting agreements usually cover the majority of employees and workers in that region. In the wage bargaining process in East Germany during the Reunification the representatives of the employer side had no incentive to keep wages low which explains the extreme wage increases (see e.g., Franz 1992).

12. Notice that — as explained above in the data section — the values for 1989 and 1990 are low since these years only reflect migration to (former) West Berlin. 


\section{References}

Akerlof, G. A., Rose, A. K., Yellen, J. L., and H. Hessenius (1991), "East Germany in from the Cold: The Economic Aftermath of Currency Union," Brookings Papers on Economic Activity, 1, 1-87.

Alecke, B. , and G. Untiedt (1999), "Determinanten der Binnenwanderung in Deutschland seit der Wiedervereinigung - Eine makroökonometrische Analyse mit Paneldaten für die Bundesländer und den Zeitraum 1991 bis 1997," University of Münster, Volkswirtschaftliche Diskussionsbeiträge Nr. 309.

Brückner, H., and P. Trübswetter (2004), "Do the Best Go West? An Analysis of the SelfSelection of Employed East-West Migrants in Germany," IZA Discussion Paper Series, Discussion Paper No. 986.

Bundesanstalt für Arbeit, Arbeitsmarkt 2002, Amtliche Nachrichten der Bundesanstalt für Arbeit, 51, Sondernummer Nürnberg 18. Juni 2003 (www.pub.arbeitsamt.de/hst/services/statistik/000100/html/jahr/index.shtml).

Burda, M. C. (2000), 'East-West German Wage Convergence after Unification: Migration or Institutions?" Paper presented at the Murphy Institute Conference on The Political Economy of Migration, Tulane University, March 2000.

Burda, M. C. (1993), 'The determinants of East-West German Migration - Some First Results," European Economic Review, 37, 452-461.

Burda, M. C., Härdle, W., Müller, M., and A. Werwatz (1998), "Semiparametric Analysis of German East-West Migration Intentions: Facts and Theory," Journal of Applied Econometrics, 13, 525-541.

Dorbritz, J., and W. Speigner (1991), "Die Deutsche Demokratische Republik - ein Einund Auswanderungsland?" Zeitschrift für Bevölkerungswissenschaft, 16(1), 67-85.

Franz, W. (1992), 'Im Jahr danach - Bestandsaufnahmen und Analyse der Arbeitsmarktentwicklung in Ostdeutschland," in Von der Plan-zur Marktwirtschaft, edited by B. Gahlen, H. Hesse, and H. J. Ramser, Tübingen: Mohr-Siebeck, 245-274.

Franz, W., and V. Steiner (1999), "Wages in the East German Transition Process - Facts and Explanations," Centre for European Economic Research Paper.

Grundmann, S. (1998), Bevölkerungsentwicklung in Ostdeutschland. Demographische Strukturen und räumliche Wandlungsprozesse seit 1945. Opladen: Leske Budrich. 
Heiland, F. (2003), "The Collapse of the Berlin Wall - Simulating State-Level East to West German Migration Patterns," in: Agent-Based Computational Demography, edited by F. Billari and A. Prskawetz, Heidelberg: Physica Verlag (Springer).

Hunt, J. (2000), "Why do people still live in East Germany?" National Bureau Of Economic Research Working Paper No. 7564.

Maretzke, S., and F.-O. Möller (1993), "Wanderungsverflechtungen zwischen den neuen und alten Bundesländern im Jahre 1991," Geographische Rundschau, 45(3), 191195.

Maretzke, S. (1998), "Regionale Wanderungsprozesse in Deutschland sechs Jahre nach der Vereinigung," in: Informationen zur Raumentwicklung 11/12, 743-762.

Parikh, A., and M. van Leuvensteijn (2002), "Internal Migration in Regions of Germany: A Panel Data Analysis", European Network of Economic Policy Research Institute, Economics Working Paper 2002-12.

Schwarze, J. (1996), "Beeinflußt das Lohngefälle zwischen Ost- und Westdeutschland das Migrationsverhalten der Ostdeutschen?" Allgemeines Statistisches Archiv, 80, 50-68.

Sinn, H.-W. (2000), "Germany's Economic Unification: An Assessment After Ten Years," National Bureau Of Economic Research Working Paper No. 7586.

Statistisches Bundesamt, Statistisches Jahrbuch der Bundesrepublik Deutschland, 19932003. Stuttgart: Kohlhammer.

Wagner, G. (1998), "Migration Before and After Unification: Empirical Evidence and Policy Implications for Germany," in: Policy Priorities for the Unified Korean Economy, edited by Il SaKong and Kwang Suk Kim, Seoul: Institute for Global Economics.

Wendt, H. (1993/94), "Wanderungen nach und innerhalb von Deutschland unter besonderer Berücksichtigung der Ost-West Wanderungen," Zeitschrift für Bevölkerungswissenschaft, 19(4), 517-540.

Zimmermann, K. F. (1995), "Tackling the European Migration Problem," Journal of Economic Perspectives, 9(2), 45-62. 
Demographic Research - Volume 11, Article 7 